\title{
相界面析出現象と最近の実用鉄鋼材料への応用
}

\author{
船川義正
}

JFE スチール株式会社スチール研究所

J. Japan Inst. Met. Mater. Vol. 81, No. 10 (2017), pp. 447-457

(C) 2017 The Japan Institute of Metals and Materials

Overview

\section{Interface Precipitation and Application to Practical Steels}

Yoshimasa Funakawa

Steel Research Laboratory, JFE Steel Corporation, Chiba 260-0835

The interface-precipitation has been observed as row carbide arrange since 1960's. Whereas the interface-precipitated carbides in steels were $\mathrm{NbC}, \mathrm{TiC}, \mathrm{VC}$ and $\mathrm{Cr}_{23} \mathrm{C}_{6}$ in the early stage, composite TiC containing Mo and $\mathrm{W}$ has been also become to observe recently. Several kinds of the mechanism of the interface-precipitation have been suggested and ledge mechanism and bowing mechanism which combined interface barging and carbide precipitation are widely accepted since the mechanisms successfully explained a large amount of the experimental results. Fine interface-precipitates in low carbon steel realize high strength steel sheets, plates, bars and rods which are non-quenched and tempered. Especially, in sheet products, in which fine carbides can be easily generated, ferritic steel of $1180 \mathrm{MPa}$ in tensile strength is successfully obtained by dispersing fine carbides with the diameter of several nano-meters. [doi:10.2320/jinstmet.J2016047]

(Received June 8, 2017; Accepted July 10, 2017; Published September 25, 2017)

Keywords: row precipitates, intersheet spacing, interface precipitation, high strength steel, low carbon steel, microalloyed steel

\section{1.は じめに}

相界面析出は, オーステナイトからフェライトへの変態時 に移動しているオーステナイトノフェライト界面に直線また は曲線状の点列, もしくは繊維状に炭化物が析出する現象で ある1). 炭化物形成元素を添加した鋼中では, 変態温度, オー ステナイト中の炭化物溶解量, $\mathrm{Mn}$ や $\mathrm{Cr}$ や Ni 等の添加によ る析出タイミングの変化により点列状炭化物の列間隔は変化 する ${ }^{2)}$.この相界面析出は, 1963年の Morrison ${ }^{3)} に よ る ~ N b$ 添 加鋼のフェライト中での列状の $\mathrm{NbC}$ 観察を皮切りに VC, $\mathrm{TiC},(\mathrm{Ti}, \mathrm{V}) \mathrm{C}$ などで相次いで報告された. Morrisonは, オーステナイトーフェライト界面上への析出とは考えず, オーステナイトーフェライト変態でフェライト中に発生した 転位上への析出の可能性に言及している. その後, Davenport $ら^{4)}$ がフェライト中の列状 VC は $\gamma-\alpha$ 界面上への析出であると し, Interface Precipitation と名付けて以降, 相界面上への析 出として広く知られるようになった. Fig. 1 に相界面析出物 の報告の年表を示しておく.

Davenport らは, フェライト変態途中での水焼入れで Fig. 2 に示すようなマルテンサイトーフェライト界面に並行な炭 化物列を確認した. これより, オーステナイトーフェライト 界面上に析出した炭化物が界面の前進でフェライト中に残さ れ, 再びオーステナイトーフェライト界面上に炭化物が析出 するという過程を繰り返すこことで炭化物の列が生じると報 告している. これに対し, Campbell ら ${ }^{5)}$ が1974年にオーステ ナイトーフェライト界面の移動速度の遅い $0.2 \% \mathrm{C}-12 \% \mathrm{Cr}$ 鋼
を変態途中で焼入れし，変態界面のスーパーレッジのテラス に向かってフェライト中に列状の $\mathrm{Cr}_{23} \mathrm{C}_{6}$ が析出している写真 の撮影に成功した. これによりオーステナイトーフェライト 界面のスーパーレッジのテラス上に炭化物が析出するモデル が脚光を浴びることになる. 続いて各種の炭化物で列状炭化 物が一般に観察されるようなり, メカニズムも多数報告され るようになった. さらに炭化物に限らず $\mathrm{Cu}$ でも相界面析出 ${ }^{6)}$ が認められ，相界面析出は一般的に起こりえる析出形態と考 えられるようになった．現在では相変態する金属で広く認め られ, 高性能化を担う組織形成への応用が期待される現象と なっている7,8).

1980年代末フェライトーパーライト組織中のフェライトを 相界面析出した炭化物で強化した厚鋼板が開発された ${ }^{9)} .1990$ 年代には, フェライトーパーライト組織中のフェライトを $\mathrm{TiC}$ で強化した $590 \mathrm{MPa}$ 級熱延鋼板 ${ }^{10)}$ が開発された。 そして, 相界面析出で析出強化したフェライトとマルテンサイトで構 成された伸びフランジ加工性に優れた $780 \mathrm{MPa}$ 級 Dual-Phase 鋼が開発，実用化された11)。このように，1995年までに実用 化されたフェライトを $\mathrm{TiC}$ で強化した $\mathrm{DP}$ 鋼およびフェライ トーベイナイト鋼では, フェライト中の大きさ約 $10 \mathrm{~nm}$ の $\mathrm{TiC}$ は, フェライトとマルテンサイトもしくはベイナイトと の強度差を縮めて伸びフランジ加工性を向上させるために用 いられており ${ }^{12)}$, 相界面析出を積極的に高強度化に利用する ものではなかった.

そして, 相界面析出炭化物で高強度化する鋼として, フェ ライト単一組織のマトリックス中に大きさ約 $3 \mathrm{~nm}$ の炭化物 を分散させることで伸びフランジ加工性を極限まで追求した 


\begin{tabular}{|c|c|c|c|c|c|c|c|c|c|c|}
\hline & & & 1960 & 1970 & 1980 & 1990 & 1980 & \multirow[t]{2}{*}{1990} & 2000 & 2010 \\
\hline \multirow{4}{*}{ 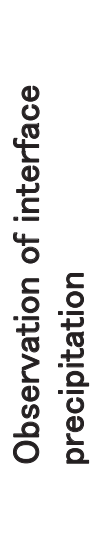 } & \multirow{2}{*}{ 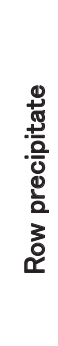 } & $\frac{\frac{0}{0}}{\frac{0}{0}}$ & $\mathrm{NbC}$ & $\begin{array}{l}\text { observa } \\
\text { TiC } \\
\mathrm{Cr}_{2}\end{array}$ & report of & $\begin{array}{l}(\mathrm{Nb}, \mathrm{V}) \\
\mathrm{Fe}_{3} \mathrm{C}\end{array}$ & ion) & & (Ti, M & $\begin{array}{l}\text { Nb) C } \\
\mathrm{C} \\
\mathrm{Mo}, \mathrm{V}) \mathrm{C}\end{array}$ \\
\hline & & 농 & & & $\mathrm{Cu}$ & & & & & $\mathrm{Fe}_{2} \mathrm{Hf}$ \\
\hline & $\begin{array}{l}\text { Fibe } \\
\text { prec }\end{array}$ & ipitate & & $\begin{array}{l}\mathrm{Ho}_{2} \mathrm{C} \\
\mathrm{Cr}_{2}\end{array}$ & & & & & & \\
\hline & $\begin{array}{l}\text { Exc } \\
\text { ste }\end{array}$ & & & $\begin{array}{r}\mathrm{AgCd}(A \\
\quad \mathrm{A}\end{array}$ & $\begin{array}{l}\mathrm{Mg}, \mathrm{Sc}, \\
\mathrm{Mg}\end{array}$ & & & & & \\
\hline 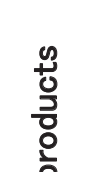 & Sh & eet & & & TS780MPa & $\begin{array}{l}\text { ade ferrite } \\
\text { TS }\end{array}$ & $\begin{array}{r}\text { rtensite } \\
\text { Pa grade } \\
\text { OMPa gra } \\
\text { TS1180 }\end{array}$ & $\begin{array}{l}\text { te-marte } \\
\text { erritic ste } \\
\text { grade fer }\end{array}$ & steel & \\
\hline$\overline{8}$ & $\mathrm{Pl}$ & te & & & & TS590 & Pa grade & ite-pearlit & eel & \\
\hline वृ. & $\begin{array}{l}\text { Fo } \\
\text { pro }\end{array}$ & $\begin{array}{l}\text { ged } \\
\text { duct }\end{array}$ & & & & & & $1000 \mathrm{MPa}$ & de ferrite- & lite steel \\
\hline
\end{tabular}

Fig. 1 Chronology of interface-precipitation observation.

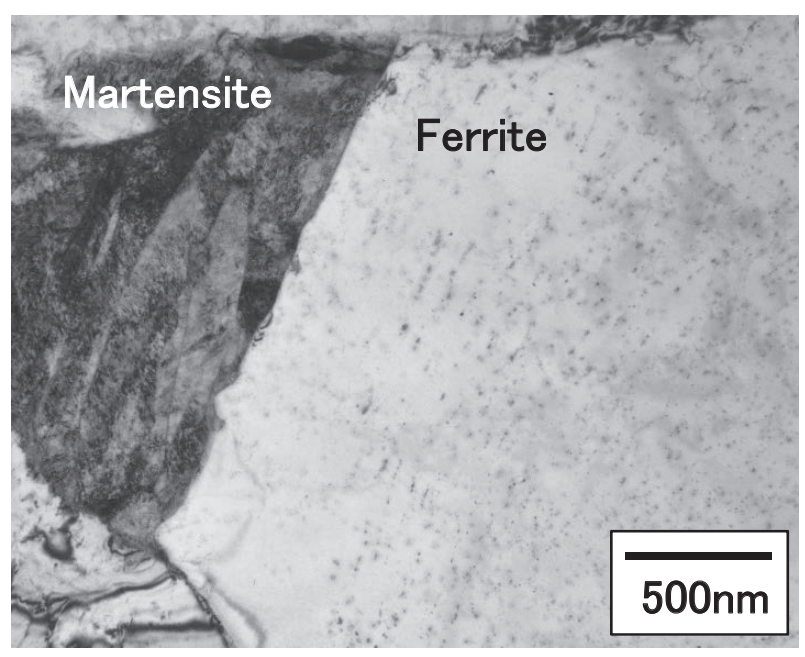

Fig. 2 Transmission electron micrograph showing martensiteferrite interface and row precipitates in 0.04 mass $\%$ C-1.5 mass $\%$ Mn- 0.2 mass \% Ti steel quenched after hot-rolling.

薄鋼板が開発され ${ }^{13)}$, 引張強さで $780 \mathrm{MPa}$ 級を超える高強度 化の手段として相界面析出が広く工業利用されるようになっ た. 本オーバービューでは鋼組成の単位は断りが無い限り mass\%を用いている.

\section{2. 相界面析出現象}

\section{1 相界面析出}

前章で示したように相界面析出は鋼中への炭化物析出に 限った現象では無いが, 本オーバービューでは事例の多い鋼 中炭化物析出を例に解説する. 相界面析出物は Fig. 3 のよう

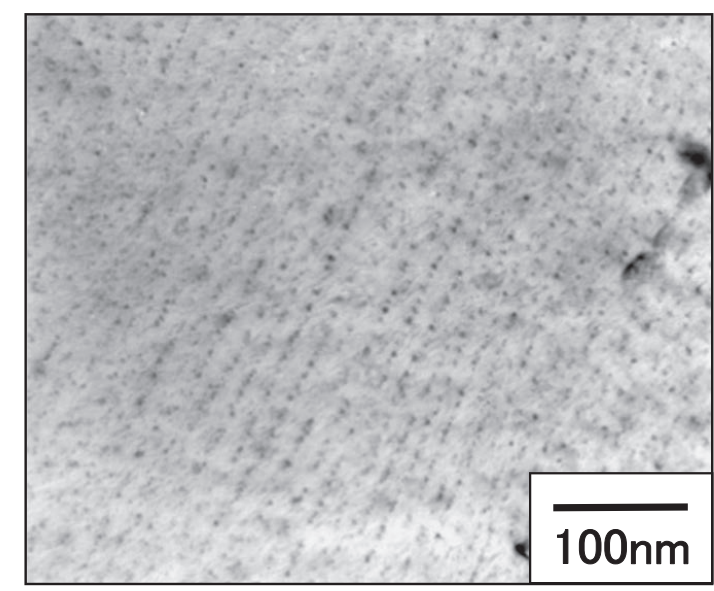

Fig. 3 Transmission electron micrograph showing interfaceprecipitated (Ti, Mo) C in low carbon steel.

な特徵的な形態で観察されることが多い. 実際には炭化物が 平面上に分散した炭化物シートとなっており, 炭化物シート 面に平行な方向からの視野では列状に観察される．炭化物列 間隔はこの炭化物シートの間隔である. Fig. 3 は低炭素鋼に $\mathrm{Ti}$ と Mo を添加して $(\mathrm{Ti}, \mathrm{Mo}) \mathrm{C}$ を相界面析出させた例である. この列状の析出は, 鉄鋼材料の組織の中でも目を惹く現象で ある。

\section{2 相界面析出物}

相界面析出する鋼中炭化物は実用上重要な炭化物が多い. Table 1 に相界面析出が報告されている化合物を示す。単一の 炭化物としては $\mathrm{NbC}, \mathrm{TiC}, \mathrm{VC}, \mathrm{Mo}_{2} \mathrm{C}, \mathrm{Fe}_{3} \mathrm{C}$ がある. $\mathrm{Nb}$ は TMCP(Thermomechanical Control Process : 制御圧延, 制御 
Table 1 List of phases observed in interface precipitation.

\begin{tabular}{|c|c|c|c|c|c|}
\hline & Precipitate & Morphology & Chemical composition & Thermal history & Reference \\
\hline \multirow{6}{*}{$\begin{array}{l}\text { Simple } \\
\text { carbide }\end{array}$} & $\mathrm{NbC}$ & Row & $0.15 \mathrm{C}-1.11 \mathrm{Mn}-0.02 \mathrm{Nb}$ & Air-cool after rolling & 3 \\
\hline & $\mathrm{VC}$ & Row & $0.2 \mathrm{C}-2 \mathrm{~V}$ & Isothermal transformed at $600^{\circ} \mathrm{C}$ or $800^{\circ} \mathrm{C}$ in sault-bath & 14 \\
\hline & $\mathrm{TiC}$ & Row & $0.1 \mathrm{C}-0.5 \mathrm{Ti}$ & Isothermal transformed from $600^{\circ} \mathrm{C}$ to $850^{\circ} \mathrm{C}$ in sault-bath & 15 \\
\hline & $\mathrm{Mo}_{2} \mathrm{C}$ & Fibber & $0.2 \mathrm{C}-4 \mathrm{Mo}$ & Isothermal transformed at $600^{\circ} \mathrm{C}$ or $800^{\circ} \mathrm{C}$ in sault-bath & 14 \\
\hline & $\mathrm{Cr}_{23} \mathrm{C}_{6}$ & $\begin{array}{l}\text { Fibber } \\
\text { /Carbide }\end{array}$ & $0.2 \mathrm{C}-12 \mathrm{Cr}$ & Holding at $750^{\circ} \mathrm{C}$ or $650^{\circ} \mathrm{C}$ after rolling & 5 \\
\hline & $\mathrm{Fe}_{3} \mathrm{C}$ & Row & $\mathrm{Fe}-0.12 \mathrm{C}-3.28 \mathrm{Ni}$ & Isothermal transformed at $550^{\circ} \mathrm{C}$ & 16 \\
\hline \multirow{6}{*}{$\begin{array}{l}\text { Complex } \\
\text { carbide }\end{array}$} & $(\mathrm{Ti}, \mathrm{Mo}) \mathrm{C}$ & Row & $0.04 \mathrm{C}-1.5 \mathrm{Mn}-0.2 \mathrm{Ti}-0.2 \mathrm{Mo}$ & Isothermal transformed from $600^{\circ} \mathrm{C}$ to $700^{\circ} \mathrm{C}$ after rolling & 13 \\
\hline & $(\mathrm{Ti}, \mathrm{Nb}) \mathrm{C}$ & Row & $0.04 \mathrm{C}-1.3 \mathrm{Mn}-0.2 \mathrm{Ti}-0.15 \mathrm{Nb}$ & Isothermal transformed from $600^{\circ} \mathrm{C}$ to $700^{\circ} \mathrm{C}$ after rolling & 17 \\
\hline & $(\mathrm{Ti}, \mathrm{V}) \mathrm{C}$ & Row & $0.08 \mathrm{C}-0.13 \mathrm{Ti}-0.18 \mathrm{~V}$ & Isothermal transformed at $725^{\circ} \mathrm{C}$ & 18 \\
\hline & $(\mathrm{Ti}, \mathrm{Mo}, \mathrm{V}) \mathrm{C}$ & Row & $0.18 \mathrm{C}-1.34 \mathrm{Mn}-\mathrm{Ti}, \mathrm{Mo}, \mathrm{V}$ & Isothermal transformed at $600^{\circ} \mathrm{C}$ & 19 \\
\hline & $\begin{array}{l}\text { (Ti, Mo, W)C, } \\
\text { (Ti, W)C }\end{array}$ & Row & $0.05 \mathrm{C}-1.5 \mathrm{Mn}-0.09 \mathrm{Ti}-0.2 \mathrm{Mo}+\mathrm{W}$ & Isothermal transformed at $600^{\circ} \mathrm{C}$ & 20 \\
\hline & $(\mathrm{Nb}, \mathrm{V}) \mathrm{C}$ & Row & $0.2 \mathrm{C}-0.31 \mathrm{Si}-1 \mathrm{Mn}-0.15 \mathrm{~V}-0.043 \mathrm{Nb}$ & Continuously cooled from $910^{\circ} \mathrm{C}$ after rolling & 9 \\
\hline Metal & $\mathrm{Cu}$ & Row & $\mathrm{Fe}-2 \mathrm{Cu}$ & Isothermal transformed at $720^{\circ} \mathrm{C}$ & 6 \\
\hline \multirow{3}{*}{$\begin{array}{l}\text { Other } \\
\text { material }\end{array}$} & $\begin{array}{l}\mathrm{AgCd}- \\
\text { Al.Be, } \mathrm{Mg}, \mathrm{Sc}, \mathrm{Y}\end{array}$ & Row & $\mathrm{AgCd}-\mathrm{Al} . \mathrm{Be}, \mathrm{Mg}, \mathrm{Sc}, \mathrm{Y}$ & Isothermal transformed at $800^{\circ} \mathrm{C}$ & 7 \\
\hline & $\mathrm{AgCdMg}$ & Row & $\mathrm{Ag}-9 \mathrm{at} \% \mathrm{Cd}-1 \mathrm{at} \% \mathrm{Mg}$ & Isothermal transformed at $800^{\circ} \mathrm{C}$ & 8 \\
\hline & $\mathrm{Fe}_{2} \mathrm{Hf}$ & Row & $\mathrm{Fe}-9 \mathrm{Cr}-12 \mathrm{Hf}$ & Isothermal transformed at $700^{\circ} \mathrm{C}$ & 21 \\
\hline
\end{tabular}

冷却) 鋼で最も重要な元素で使用頻度も多いため, $\mathrm{NbC}$ の相 界面析出が他に先駆けていち早く観察されたと思われる。続 $く \mathrm{~V}$ 添加鋼, Ti 添加鋼での発見は Nb 添加鋼での発見から推 測できるため $\mathrm{NbC} て ゙ の$ 相界面析出の報告後直ちに発見されて も不思議はない，ステンレス鋼では界面移動が遲く炭化物も 粗大化しやすいことから $\mathrm{Cr}_{23} \mathrm{C}_{6}$ の相界面析出は観察が容易で あった，そして 2000 年代に入り鋼中 C 量が $0.1 \%$ 以下である低 炭素鋼で複合炭化物の相界面析出が多数報告されるようにな るとともに, 高強度化を目指す薄鋼板で工業的応用が盛んに 行われるようになった。

炭化物形成能の強い $\mathrm{Nb}, \mathrm{Ti}, \mathrm{V}, \mathrm{Cr}$ を含有する鋼では列状 形態が多数報告されているが, マイクロアロイングでは炭化 物を比較的形成しにくいMoの様な元素では, ファイバー状 の炭化物も観察されやすい.

\section{3 列間隔}

いずれの報告においても，等温変態での列間隔は変態温度 が低温ほど狭くなる，現在までに報告されている列間隔を変 態温度で整理した結果を Fig. 4 に示す. 異なる研究機関での 実験結果をまとめたが，炭化物形成元素の種類によらず炭素 含有量ごとに同等の列間隔を示して抢り, 炭素含有量の増加 で列間隔は狭小化する. $600^{\circ} \mathrm{C}$ 程度の低温で変態した場合, 炭 素含有量や炭化物形成元素によらず列間隔はほぼ一定となる. オーステナイトーフェライト界面移動速度が速い程スーパー レッジの高さが低くなるため ${ }^{25)}$, オーステナイトーフェライ 卜界面での炭素分配による界面移動速度で列間隔が決まると 考えられる. 一方で, 炭化物形成には炭化物形成元素の拡散 も不可欠であり炭化物形成元素の振る舞いに未解明な点があ る. な打，オーステナイトーフェライト界面での高速拡散を 考慮すれば定性的な説明は可能だが, 炭化物形成に見合う量

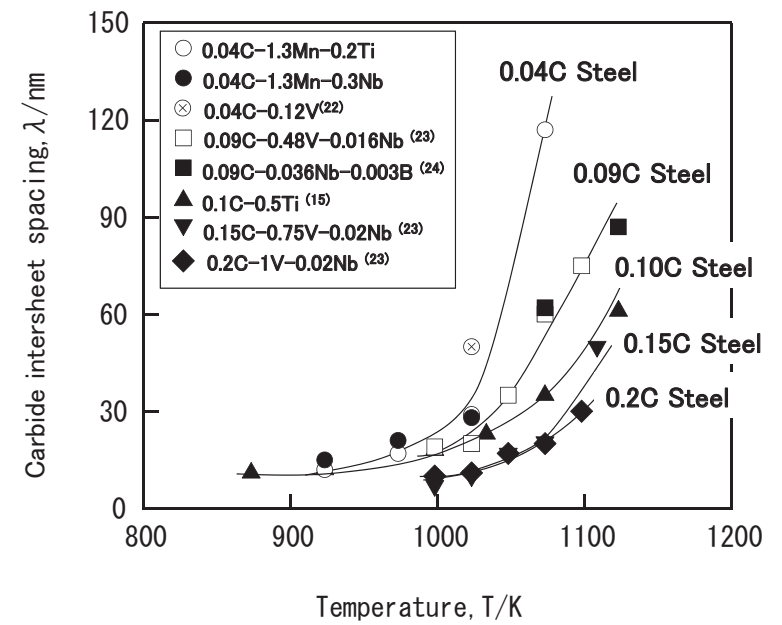

Fig. 4 Carbide intersheet spacing of isothermally transformed low carbon steels.

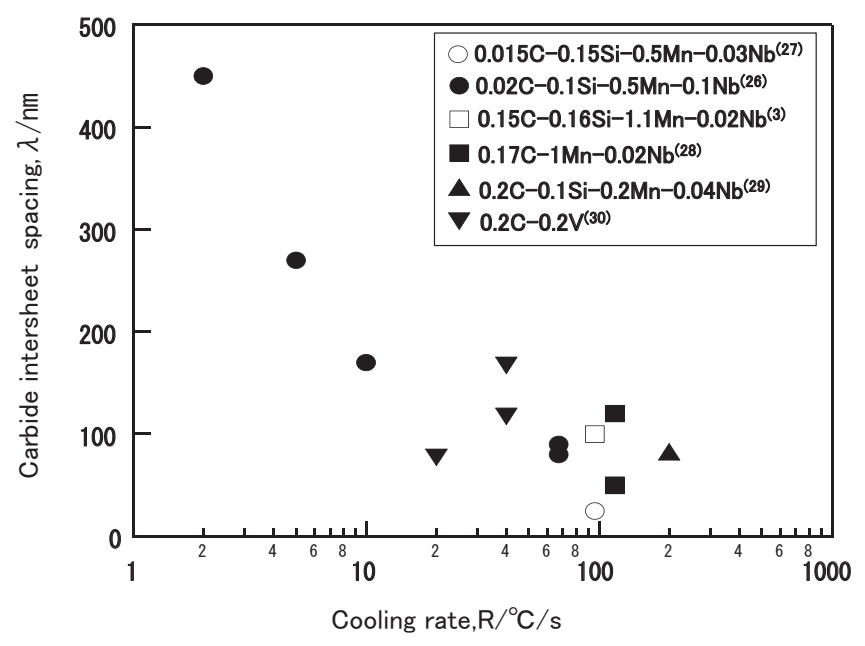

Fig. 5 Carbide intersheet spacing in continuously cooled low carbon steels ${ }^{27}$. 
Table 2 List of carbide intercheet spacing and carbide size in continuously cooled low carbon steels.

\begin{tabular}{|c|c|c|c|c|c|c|c|c|c|c|c|c|c|c|}
\hline \multirow{2}{*}{ No. } & \multicolumn{7}{|c|}{ Chemical composition [mass\% ] } & \multirow{2}{*}{ Thermal history } & \multirow{2}{*}{$\begin{array}{l}\text { Cooling } \\
\text { rate } \\
{\left[{ }^{\circ} \mathrm{C} / \mathrm{min}\right]}\end{array}$} & \multirow{2}{*}{ Deformation } & \multirow{2}{*}{$\begin{array}{l}\text { Carbide } \\
\text { size } \\
{[\mathrm{nm}]}\end{array}$} & \multirow{2}{*}{$\begin{array}{l}\text { Spacing } \\
\text { range } \\
{[\mathrm{nm}]}\end{array}$} & \multirow{2}{*}{$\begin{array}{l}\text { Spacing } \\
{[\mathrm{nm}]}\end{array}$} & \multirow{2}{*}{ Reference } \\
\hline & $\mathrm{C}$ & $\mathrm{Si}$ & $\mathrm{Mn}$ & $\mathrm{Nb}$ & V & $\mathrm{Al}$ & $\mathrm{N}$ & & & & & & & \\
\hline 2 & 0.17 & 0.04 & 0.95 & 0.02 & & 0.005 & 0.004 & $\begin{array}{l}\text { Normalized at } 870^{\circ} \mathrm{C} \text { for } \\
0.5 \mathrm{~h} \rightarrow \text { Quenched }\end{array}$ & 117 & $\begin{array}{l}\text { Hot rolled : finished at } \\
895 \sim 905^{\circ} \mathrm{C}\end{array}$ & & & 120 & 32 \\
\hline 3 & 0.17 & 0.04 & 0.95 & 0.04 & & 0.005 & 0.004 & $\begin{array}{l}\text { Normalized at } 870^{\circ} \mathrm{C} \text { for } 0.5 \mathrm{~h} \rightarrow \\
\text { Quenched }\end{array}$ & 117 & $\begin{array}{l}\text { Hot rolled : finished at } \\
895 \sim 905^{\circ} \mathrm{C}\end{array}$ & $<50$ & $40-100$ & 50 & 32 \\
\hline 4 & 0.15 & 0.16 & 1.11 & 0.02 & & & 0.005 & $\begin{array}{l}\text { Normalized at } 900^{\circ} \mathrm{C} \text { for } 1 \mathrm{~h} \rightarrow \text { Air } \\
\text { cooled }\end{array}$ & 96 & $\begin{array}{l}\text { Hot rolled : } 1200^{\circ} \mathrm{C} \\
\rightarrow 800-900^{\circ} \mathrm{C}, \quad 6 \text { passes }\end{array}$ & & & 100 & 3 \\
\hline 5 & 0.2 & 0.1 & 0.2 & 0.04 & & 0.006 & 0.001 & $\begin{array}{l}1200^{\circ} \mathrm{C} \times 0.5 \mathrm{~h} \rightarrow \text { Cooled continuously } \\
\text { from } 1200^{\circ} \mathrm{C} \text { to } 500^{\circ} \mathrm{C}\end{array}$ & 200 & Rolled & & & 80 & 29 \\
\hline 6 & 0.2 & 0.02 & 0.01 & & 0.2 & & 0.0016 & $\begin{array}{l}1200^{\circ} \mathrm{C} \times 2 \mathrm{~h} \rightarrow \text { Cooled continuously } \\
\text { from } 1200^{\circ} \mathrm{C} \text { to room temp. } \rightarrow \\
\text { tempered at } 700^{\circ} \mathrm{C} \text { for } 1 \mathrm{~h}\end{array}$ & 40 & Cold rolled & $10 \sim 20$ & & 120 & 30 \\
\hline 7 & 0.2 & 0.02 & 0.01 & & 0.2 & & 0.0016 & $\begin{array}{l}1200^{\circ} \mathrm{C} \times 2 \mathrm{~h} \rightarrow \text { Cooled continuously } \\
\text { from } 1200^{\circ} \mathrm{C} \text { to room temp. }\end{array}$ & 20 & Cold rolled & $<50$ & & 80 & 30 \\
\hline 8 & 0.2 & 0.02 & 0.01 & & 0.2 & & 0.0016 & $\begin{array}{l}1200^{\circ} \mathrm{C} \times 2 \mathrm{~h} \rightarrow \text { Cooled continu- } \\
\text { ously from } 1200^{\circ} \mathrm{C} \text { to room temp. }\end{array}$ & 40 & Cold rolled & $10 \sim 20$ & $120-240$ & 170 & 30 \\
\hline 9 & 0.02 & 0.1 & 0.5 & 0.1 & & 0.004 & 0.001 & $1260^{\circ} \mathrm{C} \times 0.5 \mathrm{~h} \rightarrow$ Air cooled & 67 & $\begin{array}{l}\text { Hot rolled : } 1260^{\circ} \mathrm{C} \rightarrow 900^{\circ} \mathrm{C} \text {, } \\
\text { then air cooled from } 900^{\circ} \mathrm{C} \\
\text { to room temp. }\end{array}$ & & $80-150$ & 90 & 26 \\
\hline 10 & 0.02 & 0.1 & 0.5 & 0.1 & & 0.004 & 0.001 & $1260^{\circ} \mathrm{C} \times 0.5 \mathrm{~h} \rightarrow$ Furnace cooled & 10 & $\begin{array}{l}\text { Hot rolled : } 1260^{\circ} \mathrm{C} \rightarrow 900^{\circ} \mathrm{C} \text {, } \\
\text { then air cooled from } 900^{\circ} \mathrm{C} \\
\text { to room temp. }\end{array}$ & $5 \sim 15$ & $100-275$ & 170 & 26 \\
\hline 11 & 0.02 & 0.1 & 0.5 & 0.1 & & 0.004 & 0.001 & $1260^{\circ} \mathrm{C} \times 0.5 \mathrm{~h} \rightarrow$ Furnace cooled & 5 & $\begin{array}{l}\text { Hot rolled : } 1260^{\circ} \mathrm{C} \rightarrow 900^{\circ} \mathrm{C} \text {, } \\
\text { then air cooled from } 900^{\circ} \mathrm{C} \\
\text { to room temp. }\end{array}$ & $10 \sim 25$ & $150-800$ & 270 & 26 \\
\hline 12 & 0.02 & 0.1 & 0.5 & 0.1 & & 0.004 & 0.001 & $1260^{\circ} \mathrm{C} \times 0.5 \mathrm{~h} \rightarrow$ Furnace cooled & 2 & $\begin{array}{l}\text { Hot rolled : } 1260^{\circ} \mathrm{C} \rightarrow 900^{\circ} \mathrm{C} \text {, } \\
\text { then air cooled from } 900^{\circ} \mathrm{C} \\
\text { to room temp. }\end{array}$ & $20 \sim 50$ & $250-3750$ & 450 & 26 \\
\hline 13 & 0.02 & 0.1 & 0.5 & 0.1 & & 0.004 & 0.001 & $1260^{\circ} \mathrm{C} \times 0.5 \mathrm{~h} \rightarrow$ Air cooled & 67 & $\begin{array}{l}\text { Hot rolled : } 1260^{\circ} \mathrm{C} \rightarrow 900^{\circ} \mathrm{C} \text {, } \\
\text { then air cooled from } 900^{\circ} \mathrm{C} \\
\text { to room temp. }\end{array}$ & & $40-100$ & 80 & 26 \\
\hline
\end{tabular}

の拡散が可能かは未解明である．列間隔はメカニズムごとに その支配因子が異なるが，いずれにおいても定量的に列間隔 を精度良く予言できる様になるにはモデルのさらなる深化が 必要である。

一方，連続冷却時の列間隔については Gray らの論文 ${ }^{26)} に$ まとめられている. Fig. 5 に冷却速度と列間隔との関係を示 す. 冷却速度の増大で列間隔は狭くなるが，列間隔には大き な分散も認められる。これは過冷却による変態温度の低温化 や実際の局所的な変態開始温度(観察位置の問題)の影響を受 けていると考えられる，原論文から読み取った值を Table 2 に示しておく

\section{4 炭化物径}

Fig. 6 に等温変態温度と $\mathrm{TiC}$ および $\mathrm{NbC}$ 径との関係 33 を示 す. 変態温度の低温化で炭化物は急速に微細化し, $650^{\circ} \mathrm{C}$ 以下 でほほ一定となる．大きさは円相当径で $3 \mathrm{~nm}$ 程度と報告さ れているものもあるが，実際は炭化物とマトリックスとの整 合性に異方性が存在するため, 高さが低い直方体であると考 えられる. Fig. 7 に微細析出した炭化物の格子像を示す. 板 状の炭化物を真横から観察しているため細長く観察されてい る. マトリックスと炭化物長辺との界面は整合性が良く Backer-Nutting の方位関係 ${ }^{34)}$ を有している。 な挹，連続冷却

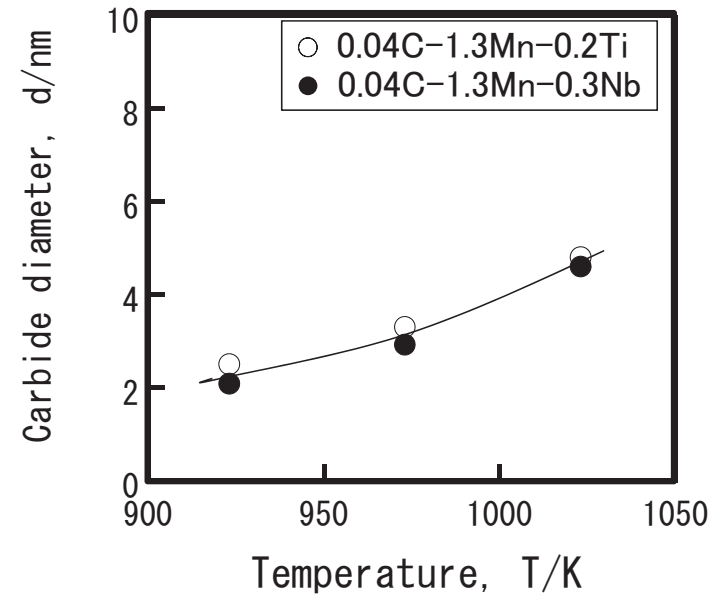

Fig. 6 Carbide diameter of isothermally transformed microalloyed low carbon steels.

で得られた炭化物の大きさも Table 2 に示しておいた.

\section{3. 相界面析出メカニズム}

現在までに提案されてきた代表的なメカニズムを Table 3 にまとめる. 


\subsection{Gray モデル(初期モデル)}

Fig. ${ }^{26)}$ に示す直線状のオーステナイトーフェライト界面の 前進で炭化物形成元素が掃き集められて濃化し, 界面拡散で 界面上に炭化物が形成する。これを繰り返してオーステナイ トーフェライト界面に平行に炭化物の列が形成してゆくモデ ルを Gray らは提案した。一方, DavenportらはCの濃化が オーステナイトーフェライト界面の移動の律速になるとした. Fig. $9^{4)}$ に模式図を示す. 界面が移動すると炭素がオーステナ イトーフェライト界面のオーステナイト側に濃化する。この 炭素の濃化により界面移動は停止する. 濃化した炭素が炭化 物形成で消費されると界面は駆動力を得て再び前進し, 前進 に伴い再び炭素が界面上に濃化する。この繰り返しにより列 状の炭化物が形成される. 近年, この古典レッジモデルに析 出を組み合わせ，列状析出形態を表現するモデルが報告され ている ${ }^{39)}$. このモデルでは, ピン止めしている炭化物間の オーステナイトーフェライト界面の一部がレッジをつくりな

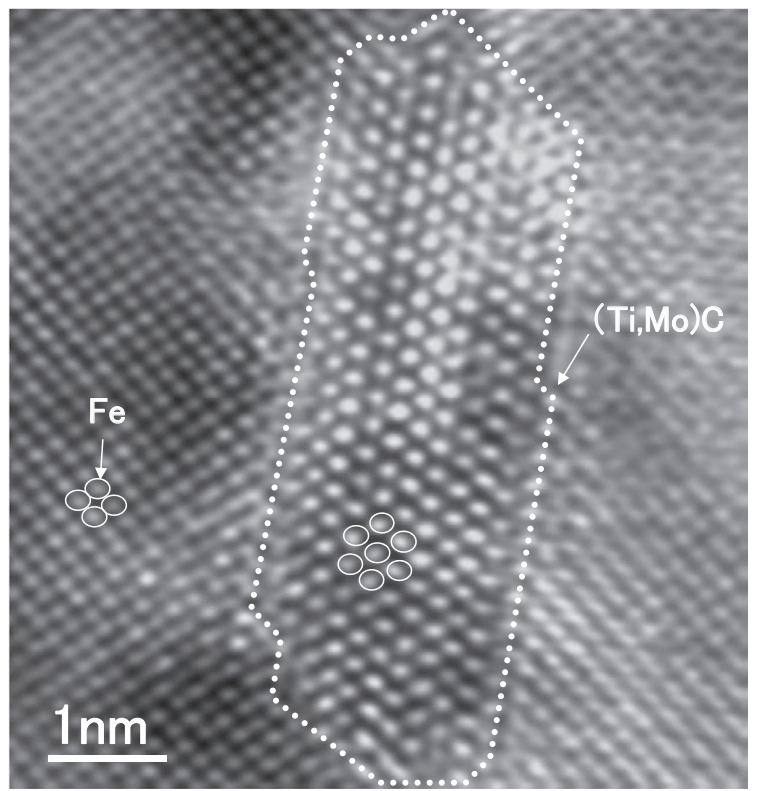

Fig. 7 Transmission electron micrograph showing lattice image of $(\mathrm{Ti}, \mathrm{Mo}) \mathrm{C}$ in low carbon ferritic steel.
がら前進し，隣接するスーパーレッジどうしが合体してピン 止めが外れることで界面全体が炭化物を列状に残して前進す る.

変態途中で焼入れしたときに Fig. 2 に示すようなフェライ トとマルテンサイトとの界面に炭化物列が平行になる現象を このメカニズムは説明できるが, 次の Ledge メカニズムの方 がより多くの現象を説明できることから現在ではあまり扱わ れていない.

\subsection{Ledge メカニズム}

Fig. 10 ${ }^{35)}$ に Ledge メカニズムの模式図を示す．変態中の オーステナイトーフェライト界面は平面であり, 整合界面で あるテラス上に炭化物が析出する。炭化物列間隔はオーステ ナイトーフェライト界面のスーパーレッジの高さに等しい. Ledge メカニズムで直線状の炭化物列は説明できることと, 変態途中の鋼を焼き入れることでオーステナイトーフェライ

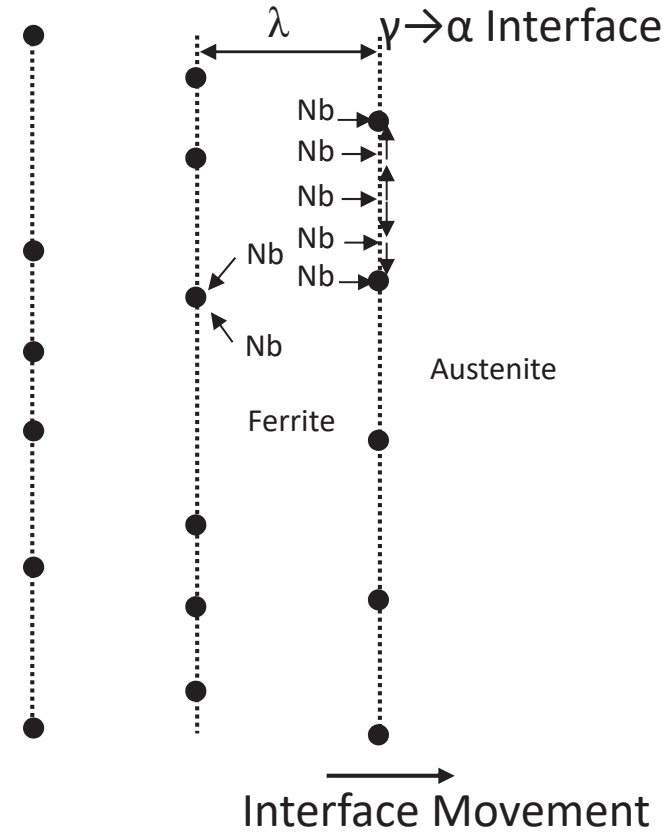

Fig. 8 Gray model explaining interface precipitation ${ }^{26)}$.

Table 3 List of interface precipitation models.

\begin{tabular}{|c|c|c|c|}
\hline Model & Mechanism & Steel (mass\%) & Reference \\
\hline Gray Model & $\begin{array}{l}\text { Carbides form at austenite-ferrite interface after the interface stops by carbon concen- } \\
\text { tration in the interface. Carbide row is parallel to the interface. }\end{array}$ & $\begin{array}{l}0.022 \mathrm{C}-0.12 \mathrm{Si}^{-}-0.52 \mathrm{Mn}^{-} \\
0.020 \mathrm{P}-0.020 \mathrm{~S}-0.008 \mathrm{Al}- \\
0.001 \mathrm{~N}-0.10 \mathrm{Nb}\end{array}$ & 26 \\
\hline \multirow{2}{*}{ Ledge Mechanism } & \multirow{2}{*}{$\begin{array}{l}\text { Carbides are generated on the ledge of the ferrite-austenite interface. Direction of the } \\
\text { interface movement are parallel to the carbide rows which is straight. }\end{array}$} & $0.26 \mathrm{C}-1.86 \mathrm{~V}$ など & 4 \\
\hline & & $0.2 \mathrm{C}-12 \mathrm{Cr}$ & 5 \\
\hline $\begin{array}{l}\text { Bowing Mechanism \& Quasi- } \\
\text { ledge Mechanism }\end{array}$ & $\begin{array}{l}\text { Randomly dispersed carbides are generated at the high energy interface in bowing } \\
\text { mechanism. Carbides pin the interface which is bulging. } \\
\text { Quasi-ledge mechanism is the hybrid of ledge and bowing mechanism, which can } \\
\text { describe curve carbide rows. }\end{array}$ & $0.2 \mathrm{C}-10 \mathrm{Cr}$ & 35 \\
\hline Eutectoid Decomposition Model & $\begin{array}{l}\text { The mechanism likes pearlite transformation. Fiber carbide grows to the parallel direc- } \\
\text { tion of terrace on ledge. }\end{array}$ & $0.11 \mathrm{C}-1.95 \mathrm{Mo}$ & 36 \\
\hline Solute-Drag Nucleation Model & $\begin{array}{l}\text { The mechanism can explain fiber shaped carbide. The long axis of carbide fiber is verti- } \\
\text { cal to the interface. In the case of row precipitation, row is parallel to the austenite-fer- } \\
\text { rite interface. }\end{array}$ & V-bearing steel & 37 \\
\hline
\end{tabular}




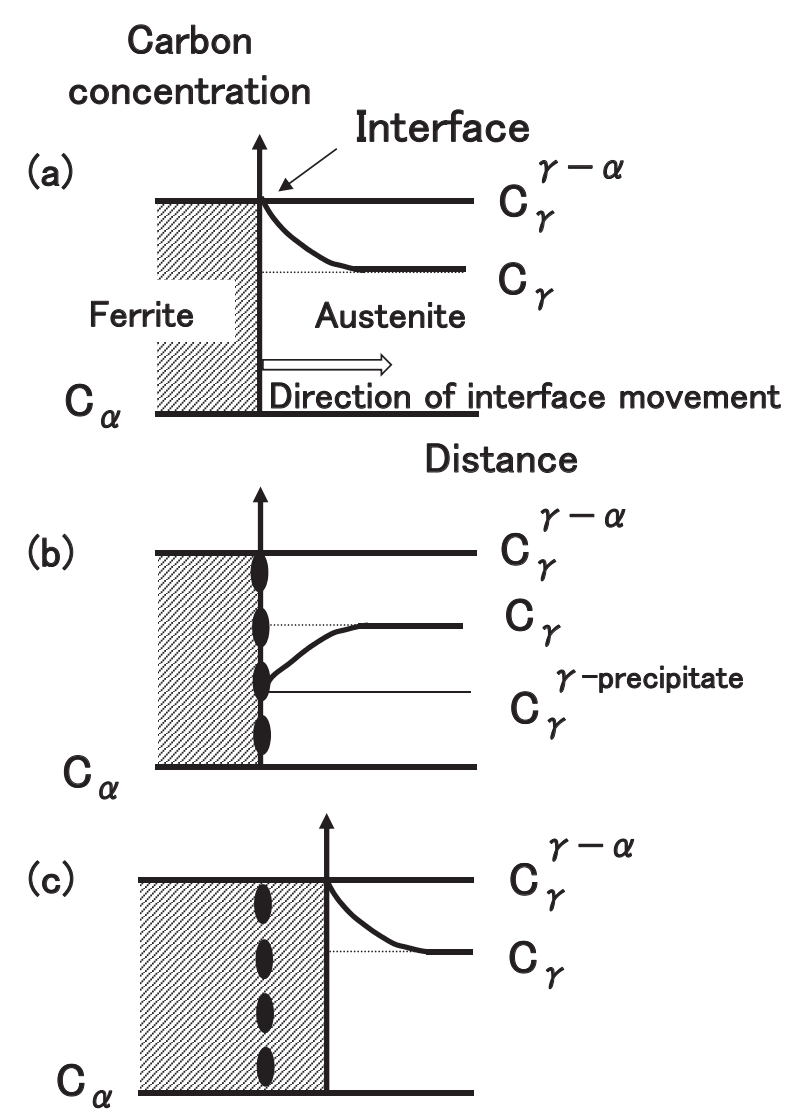

Fig. 9 Movement of austenite-ferrite interface controlled by carbon concentration after Davenport ${ }^{4}$;

$C_{\gamma}$; Equilibrium carbon concentration in $\gamma$,

$C_{\alpha} ;$ Equilibrium carbon concentration in $\alpha$,

$C_{\gamma}^{\gamma-\alpha}$; Carbon concentration on $\gamma$ side interface when interface stops, $C_{\gamma}^{\gamma-\text { precipitate; }}$ Equilibrium carbon concentration on $\gamma$-carbide interface.

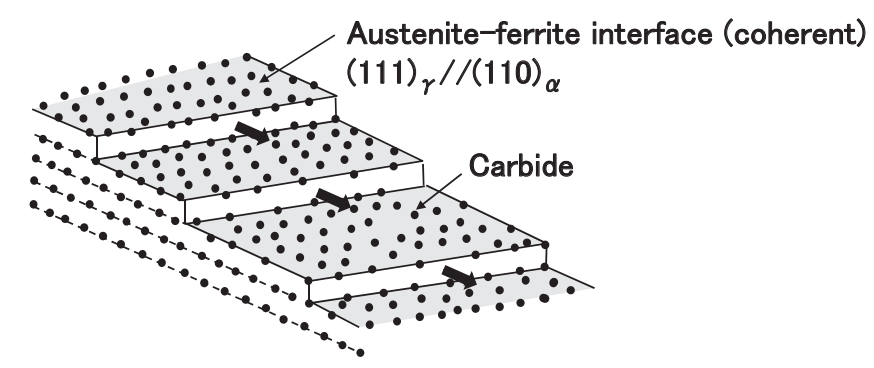

Fig. 10 Schematic illustration of ledge mechanism ${ }^{35}$.
卜界面を凍結した $\mathrm{Cr}$ 添加鋼において $\mathrm{Cr}_{23} \mathrm{C}_{6}$ が Fig. 10 のよう

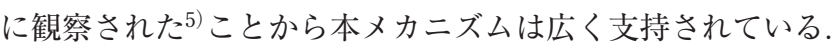
なお，炭化物とマトリックスとは Baker-Nutting の関係 ${ }^{34)}$ 有している.

\subsection{Bowing メカニズムおよび Quasi-ledge メカニズム}

Fig. 11 に Bowing メカニズム ${ }^{40)}$ の模式図を示す。直線状の オーステナイトーフェライト界面上に析出した炭化物により 界面が局所的にピン止めされた状態から炭化物間の界面が進 行方向前面に張り出し, 界面に沿った炭化物形成元素の拡散 で炭化物が張り出した界面上に析出して成長する。炭化物成 長でピン止めが外れ，炭化物を列状に残して界面が前進する メカニズムである.このメカニズムではランダムに炭化物が 分散する.

Ledge メカニズムのテラス部で Bowing メカニズムで炭化 物の形成と界面の前進が生じるとするのが Quasi-ledge メカ ニズムである，Quasi-ledgeメカニズムで，しばしば観察さ れる湾曲した炭化物列を説明することができる. Fig. 12 に Quasi-Ledge メカニズムの模式図 ${ }^{35)}$ を示す。炭化物シート内 の炭化物分布はランダムであることと, 炭化物シートが一定 間隔で並ぶことを説明できる. Quasi-Ledge メカニズムでは, オーステナイトーフェライト界面は非整合であり $\mathrm{NbC}, \mathrm{TiC}$, $\mathrm{VC}$ などの $\mathrm{NaCl}$ 型の炭化物はオーステナイトと Cube-Cube の関係を有しているとされる. Ledge と Quasi-Ledge の生じ る条件の差異は明らかではないが，オーステナイトーフェラ イト界面の移動速度が遅い整合界面で Ledge メカニズムを示

Austenite-ferrite interface(incoherent)

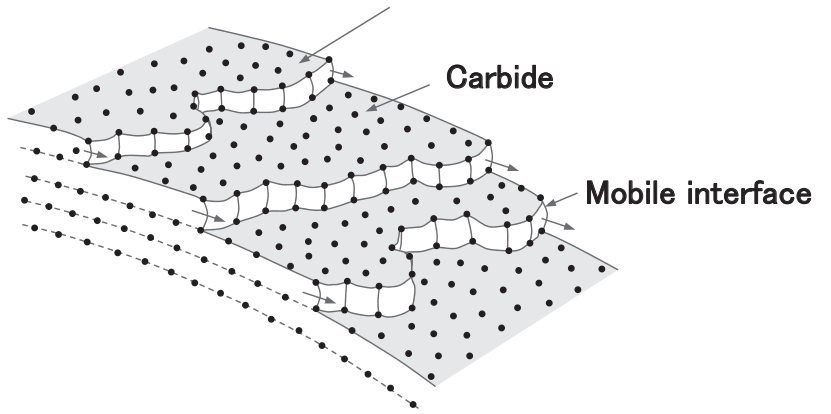

Fig. 12 Schematic illustration of quasi-ledge mechanism ${ }^{35)}$.
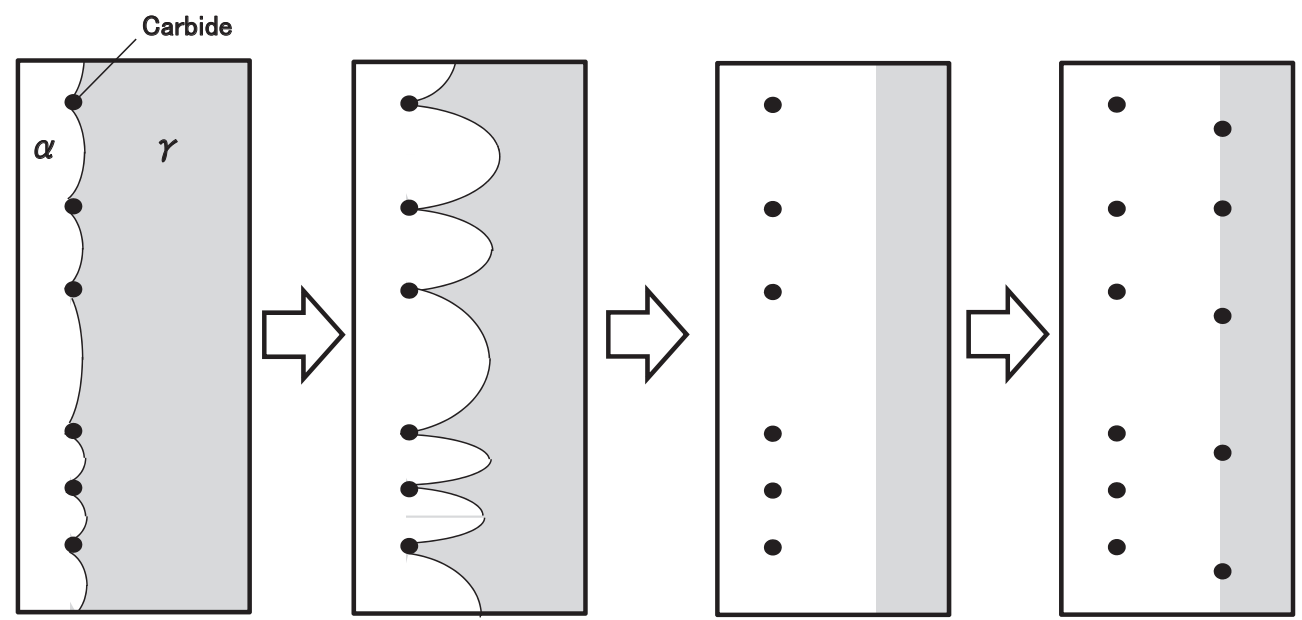

Fig. 11 Schematic illustration of bowing mechanism. 
す写真が撮影されている一方で Quasi-Ledge メカニズムを直 接示す写真が撮影されていないことを考えると, 界面移動速 度が速いほど Quasi-Ledge が生じやすいのではないかと思わ れる。

近年では, Bowing メカニズムに局所平衡の考え方を組み込 んで列状の炭化物の並びを説明するモデルが報告されてい る ${ }^{41)}$. このモデルでは, 炭化物でピン止めされた析出物間の
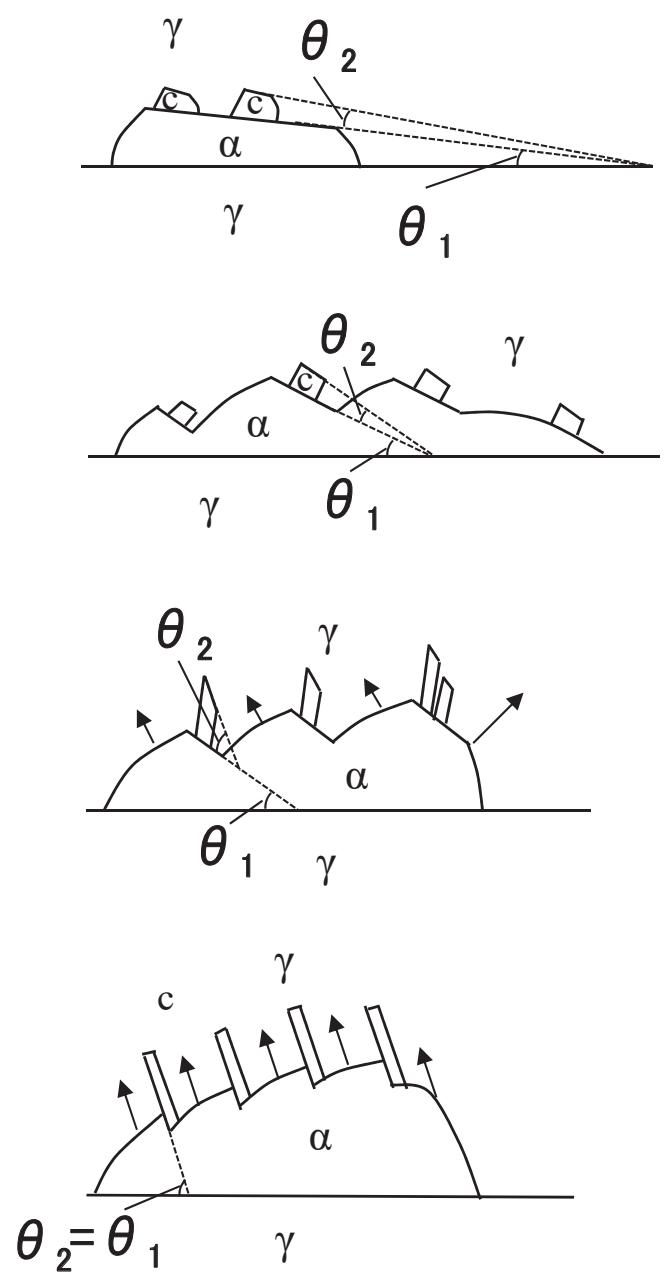

Fig. 13 Schematic illustration of eutectoid mechanism ${ }^{36)}$.
オーステナイトーフェライト界面が炭化物列間隔の高さの レッジを形成し, このレッジが炭化物列と平行な方向に拡大 することで新たなオーステナイトーフェライト界面および炭 化物が形成される。 また，このモデルに偏析とソリュートド ラッグを組み込み, 炭化物形成元素のスーパーレッジ部での 移動を考慮したモデルも報告されている ${ }^{42)}$.

\section{4 共析メカニズム}

Fig. 13 に共析メカニズムの模式図 ${ }^{36)}$ を示す。 パーライトと 同様に炭化物成長方向とフェライトの成長方向が同一方向に 向いており，フェライトアリオロモロフの段差部分に炭化物 が析出し, この析出物によりテラスが分断されるためフェラ イトのテラス部分はテラスに垂直な方向に成長するモデルで ある. ファイバー状の炭化物形成も扱っているが, 初期モデ ルに近い. Fig. 13 でフェライトー炭化物界面とオーステナイ トーフェライト界面のなす角 $\theta_{1}$ とオーステナイトー炭化物界 面とオーステナイトーフェライト界面のなす角 $\theta_{2}$ が一致する と棒状に析出, $\theta_{1}$ より $\theta_{2}$ が小さいと点列状の炭化物を形成す ると考える.

\subsection{Solute-drag nucleation モデル}

オーステナイトーフェライト界面上に炭化物形成元素と炭 素が濃化し界面の移動が停止する。これらの結合で界面に炭 化物が形成すると Solute drag 効果が無くなり界面の移動度が 上昇して界面が前進する. 界面の移動により再び炭化物形成 元素と炭素が界面に濃化して Solute drag 効果で界面が停止す る.これを繰り返すことで一定距離に列状の炭化物が形成す るのが Solute drag nucleation モデルである. Fig. 14 に模式 四 ${ }^{37)}$ を示す.

近年, Solute drag でオーステナイトーフェライト界面移動 速度を規定したモデルも提案されており, フェライト核生成 点からの距離で炭化物の列間隔が減少することを説明した ${ }^{43)}$.

\subsection{Solute-depletion モデル}

Fig. $15^{26)}$ に模式図を示す. 界面に炭化物が析出して界面が 前進するのは Solute-drag nucleation モデルと同じであるが,

(a)

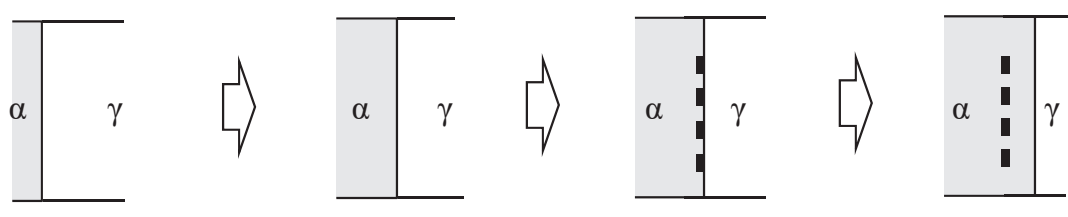

(b)

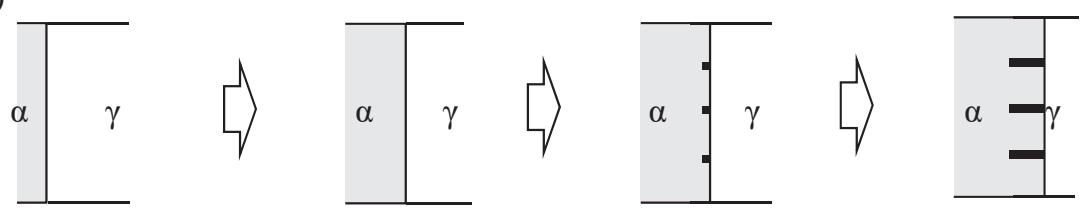

Fig. 14 Schematic illustration of solute-drag nucleation mode ${ }^{37)}$. 
Interphase Precipitation(solute-depletion model)

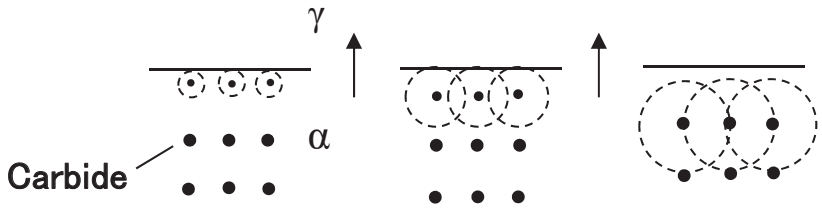

- - Boundary of zone depleted in solute as a result of particle growth

Fiber Precipitation
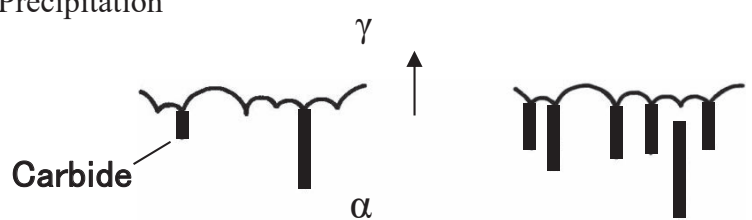

Fig. 15 Schematic illustration of solute-depletion model ${ }^{38)}$.

炭化物周囲の炭化物形成元素は炭化物析出で消費されてしま うので界面はこの炭化物形成元素の枯渇範囲まで前進する. この場合，炭化物が点では無く界面に垂直に伸びることで針 状の炭化物析出が並んで生じる。

以上のように実験結果を説明するためのモデルが数多く提 案されているが，現在これらすべてを統一して説明できるモ デルは無い。また, 逆に炭素量や温度により相界面析出機構 は異なり複数の機構が同時に生じる可能性もある。

\section{4. 最近での工業的応用例}

\section{1 相界面析出を利用した自動車用高加工性高強度熱延鋼板}

\section{(a) フェライトーパーライト鋼}

相界面析出炭化物を用いた高強度化を指向したものではな いが，フェライトーパーライト組織では得られない $590 \mathrm{MPa}$ 級の引張強さを得るために TiC をフェライト中に析出させた 析出強化薄鋼板が開発された。 $0.06 \% \mathrm{C}-0.25 \% \mathrm{Si}-0.5 \% \mathrm{Mn}$ の組成の鋼に $0.2 \% \mathrm{Ti}$ を添加し強度が最大となる様に巻取温 度を制御した鋼である。自動車の足回り部品やホイール向け に実用化されていた ${ }^{44)}$

これに対し，一般用途向けに相界面析出を利用した薄鋼板 が1990年代に開発，実用化された。熱間圧延後巻取りまでの 冷却過程で $\mathrm{TiC}$ が析出するため, 鋼のオーステナイトーフェ ライト変態点を変化させることができる $\mathrm{Mn}$ の添加で強度と 延性が変化することに着想したものである. Fig. 16 に示すよ うに $0.07 \% \mathrm{C}-0.1 \% \mathrm{Ti}$ に強度ごとに TS $\times \mathrm{EL}$ を最大とする $\mathrm{Mn}$ 量を添加する鋼が実用化された ${ }^{10)}$. この鋼はフェライトー パーライト組織のフェライトが $\mathrm{TiC} て ゙$ 析出強化されている. $\mathrm{TiC}$ は相界面析出に特徵的な列状を呈しており, 引張強さ 590 $\mathrm{MPa}$ 級の薄鋼板中で $\mathrm{TiC}$ の大きさは約 $10 \mathrm{~nm}$ であった.

\section{(b) フェライトーマルテンサイト組織}

1995年には自動車サスペンション部品の高強度化を背景に, 延性の優れたフェライトーマルテンサイト鋼のフェライトを 相界面析出 $\mathrm{TiC}$ で高強度化する鋼が実用化された。 $0.08 \%$ C-1.5\% Si-1.8\% Mn-0.1\% Ti の組成を有する薄鋼板である ${ }^{45)}$.

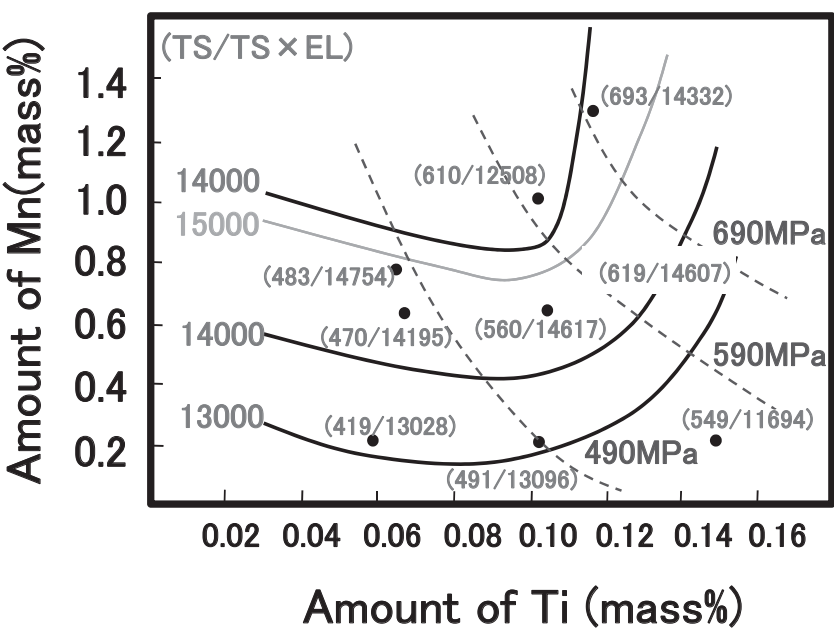

Fig. 16 Change in balance of tensile strength and elongation by amount of $\mathrm{Ti}$ and $\mathrm{Mn}^{10)}$

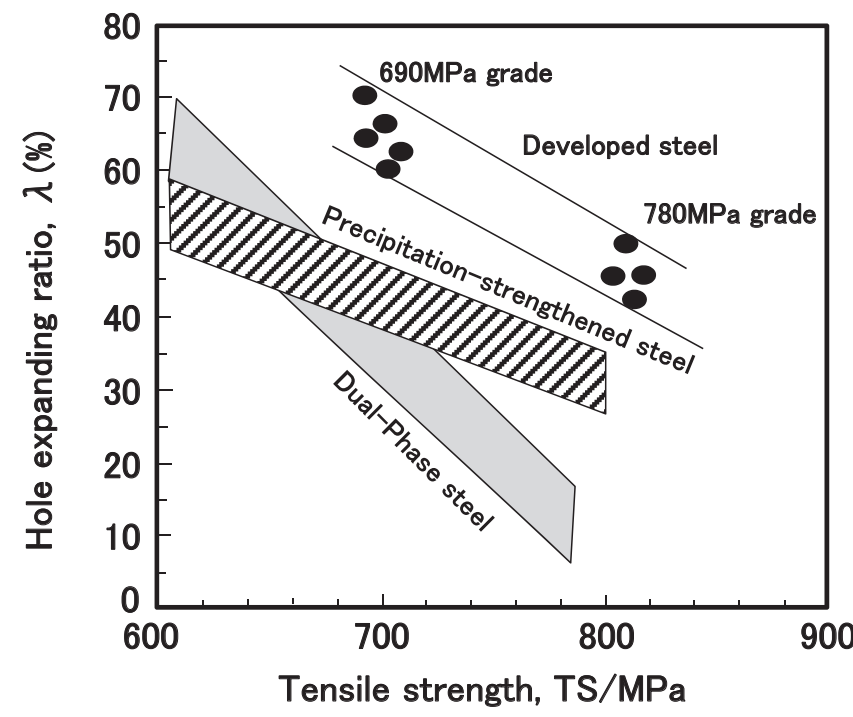

Fig. 17 Hole expanding ratio of DP steel strengthened by interface-precipitation ${ }^{45}$.

これは, 疲労強度を向上させるとともにフェライトとマルテ ンサイトの硬さの差異を原因とする伸びフランジ割れを軽減 することを目的としたものであり，フェライト中には大きさ 5 10 nm 程度の $\mathrm{TiC}$ が析出している. 伸びフランジ加工性 を Fig. 175) に示しておく

また，2008年には0.08\% C-1.5\% Si-1.8\% Mn-0.09\% Ti の 組成を有する鋼を熱間圧延後 $953 \mathrm{~K}$ まで水冷し，その後 5 〜 10秒間放冷して相界面析出した TiC を含むフェライトを形成 させ，残りをマルテンサイト化する鋼が開発された．フェラ イト中の $\mathrm{TiC}$ の大きさ制御することで疲労強度を向上させ ている ${ }^{46)}$

(c)フェライト単一組織鋼

マルテンサイトを含まないフェライト単一組織を，超微細 炭化物を相界面析出で分散させることで高強度化した伸びフ ランジ加工性の優れた高強度薄鋼板が開発された ${ }^{47)}$ 。伸びフ ランジ加工性は組織の均一化による局部伸びの増加で向上す ることが指摘されていたが, $780 \mathrm{MPa}$ 級までの高強度を実現 するだけの微細炭化物を得ることは不可能であった。 そこで, 


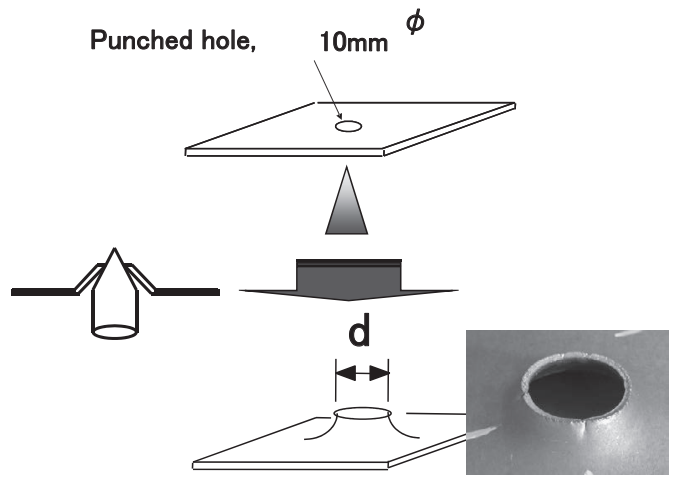

Hole-expanding ratio: $\lambda(\%)=(d-10) / 10 \times 100$

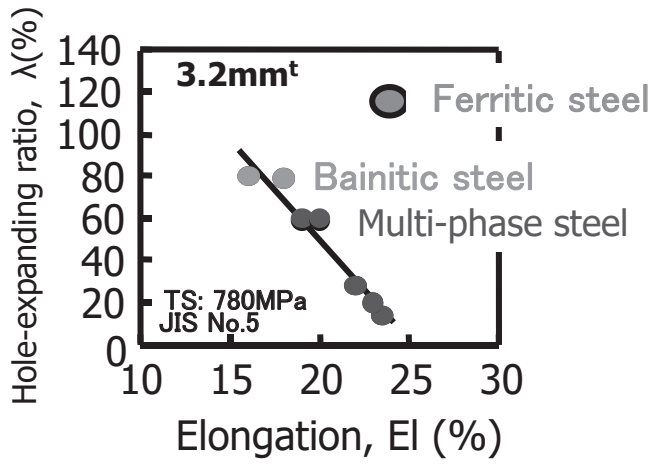

Fig. 19 Hole expanding ratio of ferritic steel ${ }^{13)}$.

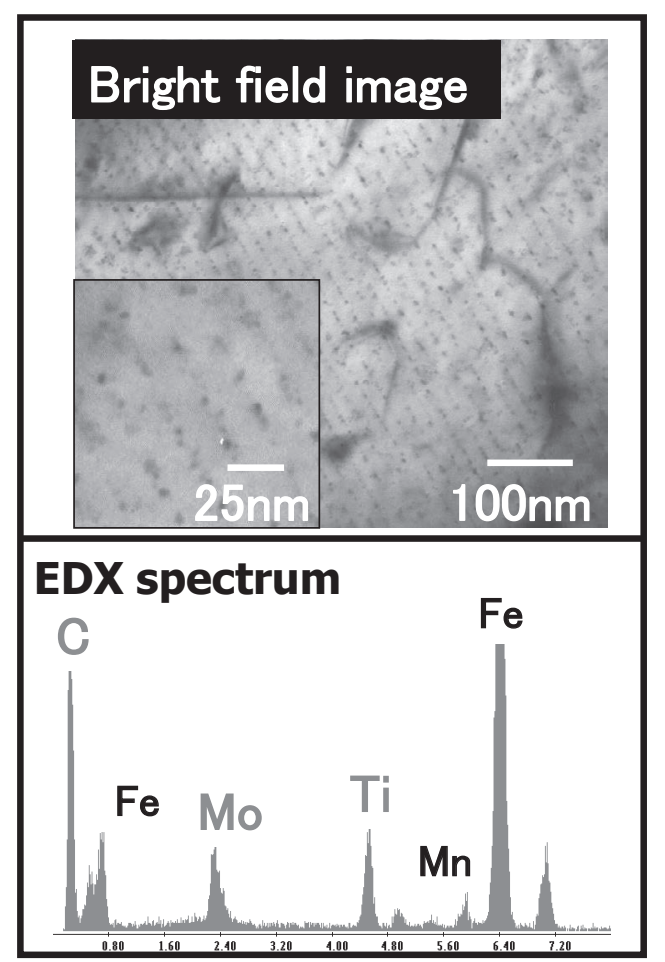

Fig. 18 Transmission electron micrograph and energy dispersion X-ray spectra of $(\mathrm{Ti}, \mathrm{Mo}) \mathrm{C}$ in ferritic low carbon stee ${ }^{13)}$.

単一の炭化物形成元素から発想を転換して, 炭化物形成元素 の複合添加で炭化物の超微細化に成功し, フェライト単一組 織で $780 \mathrm{MPa}$ 級もの高強度が実現された，具体的には，Mo を添加して $(\mathrm{Ti}, \mathrm{Mo}) \mathrm{C}$ を析出させることで微細化に成功して いる. Fig. $18^{13)}$ に炭化物の透過電子顕微鏡写真を示す.この 鋼の伸びフランジ加工性は複合組織鋼と比べて高く, 組織が 延性に富んだフェライトのため引張試験での伸びも高い。こ の状況を Fig. 1913) に示す．ささらに，表面性状を劣化させる $\mathrm{Si}$ を添加しないため疲労強度も向上する ${ }^{47)}$. また, Fig. 20 に示 すように $(\mathrm{Ti}, \mathrm{Mo}) \mathrm{C}$ は析出温度以上に保持されても粗大化し にくいため安定した析出強化量を得ることも可能である ${ }^{17)}$. 相界面析出では炭化物生成サイトであるオーステナイトー フェライト界面が鋼全体を移動するため, 過飽和固溶体から の核生成と成長よりも均一な大きさの炭化物を鋼全体に分散 させることができる。これらの原理を応用することで，さら なる高強度化, すなわち $980 \mathrm{MPa}$ 級や $1180 \mathrm{MPa}$ 級への高強

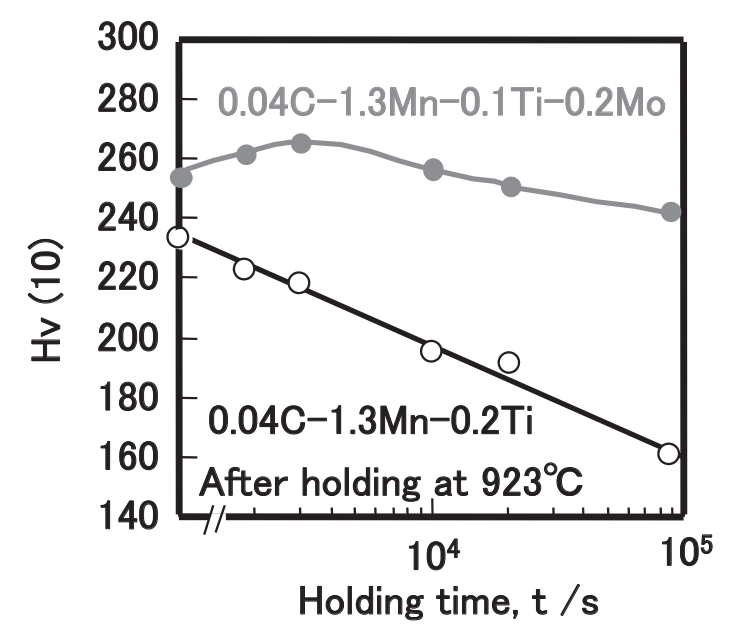

Fig. 20 Change in hardness of ferritic steels precipitationstrengthened by fine carbides of $\mathrm{TiC}$ and $(\mathrm{Ti}, \mathrm{Mo}) \mathrm{C}^{17}$.

度化も可能である. 単一の炭化物では熱間圧延での加熱温度 に上限があり, これによる炭化物溶解量の限界があるが, 複 合炭化物を用いた場合にはこの溶解量の限界を引き上げるこ とも容易であった ${ }^{48}$.

\section{$4.2 \mathrm{~V}$ 添加高炭素鋼}

$\mathrm{V}$ 添加高炭素鋼を用いた非調質機械構造用部品の開発は 1970年代から始まった ${ }^{49)}$. 当初, 非調質鋼には勒性の課題が あったが，1980年代にはVC および $(\mathrm{Nb}, \mathrm{V}) \mathrm{C}$ を用いたフェラ イトーパーライト組織を有する非調質厚鋼板も開発されてい $ろ^{9)}$. 最近では, 自動車用 JIS 規格の機械構造用鋼 S45C に炭 化物形成元素 $\mathrm{V}$ を $0.3 \sim 0.5 \%$ 添加した鋼片の加熱温度を部位 で変えて熱間鍛造することで, 部品形状に合わせて強度の異 なる部分を作り达んだ自動車の駆動系部品コンロッド用鋼材 の開発が行われた ${ }^{50,51)}$ 。この部品は, 従来の焼入れ焼戻しに よる高強度化ではなく, フェライトーパーライト組織のフェ ライトに微細な VC を相界面析出で分散させて高強度化する ものである. 強度の必要な部分は熱間鍛造時に高温加熱して $\mathrm{VC}$ を溶解し, 熱間鍛造後に等温保持して降伏点で $1000 \mathrm{MPa}$ を超える高強度を実現する一方で, 被削性の必要な部分では 低温加熱に抑えて素材中の粗大な VC の溶解を抑止して降伏 点を $900 \mathrm{MPa}$ 以下に抑えている. さらには, これに $\mathrm{Cu}$ を添 加して $\mathrm{Cu}$ での析出強化を併用する開発も行われた52). 


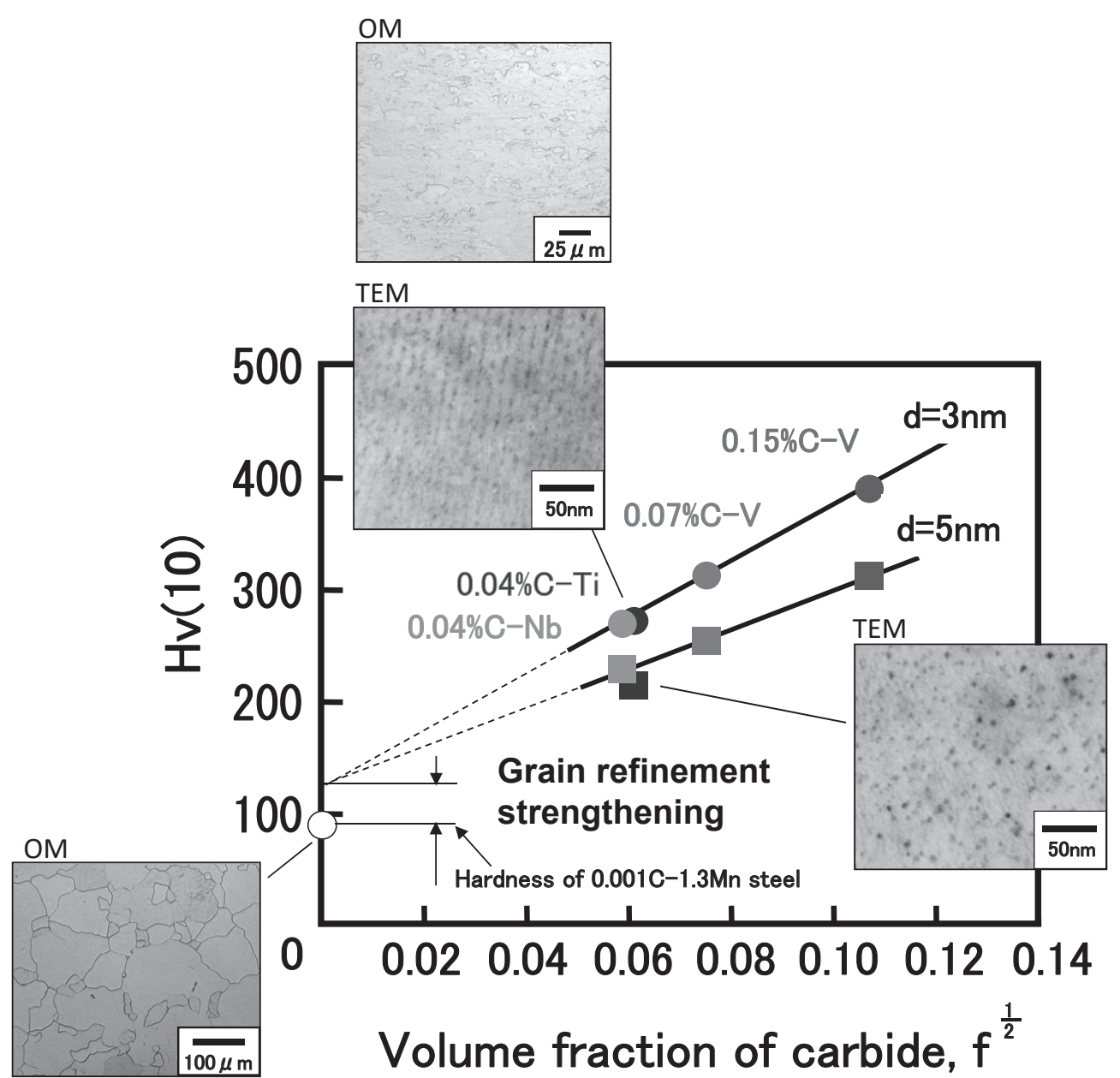

Fig. 21 Change in hardness with carbide volume fraction.

なお，個々の炭化物の等温析出や形状については大森によ る解説があることからこちらを参照されたい53).

\section{5. 今後の課題}

非調質鋼の高強度化には析出強化が有力な強化方法である. 鋼に多量の炭化物を溶解させるには限界があるが，析出物が 転位に切断されない限りは微細化による数密度を上げること でさらに高強度化が可能である。 今後はさらなる微細化によ る高強度化が課題となってゆくであろう。たとえばFig. 21 に は炭化物溶解量を $\mathrm{Ti}$ や $\mathrm{Nb}$ より多量とするために V を添加 した鋼を用い，相界面析出で得られるフェライトの硬さを炭 化物の体積分率で整理した。炭化物体積率を増加させること でまだまだ高強度を得る可能性があることが示唆される。こ れが実現できればさらに進んだ高強度鋼の開発が可能となる. 最近では，実現された微細炭化物による析出強化鋼の加工硬 化挙動も詳細に解析され始めている ${ }^{55,56)}$. これは, 加工硬化 に新たな理論や現象をもたらすものと期待される.さらには, 鋼に限らず金属材料で相界面析出を用いた機能材料が開発さ れることも期待できる．金属はその中に他の金属を溶かし込 んで熱処理で微細に分散し, 自身で複合材料を形成できるこ とに大きな魅力がある。相界面析出を用いた多種多様な新し い金属材料が今後も引き続き開発されることは大いに期待で きる。
文献

1) R. W. K. Honeycombe: Met. Sci. 14(1980) 201-214.

2) R. W. K. Honeycombe: Metall. Trans. A 7 (1976) 915-936.

3) W. B. Morrison: J. ISI 201 (1963) 317-325.

4) A. T. Davenport and R. W. K. Honeycombe: Proc. Roy. Soc. Lond, A 322(1971) 191-205.

5) K. Campbell and R. W. K. Honeycombe: Met. Sci. 8(1974) 197203.

6) R. A. Ricks, P. R. Howell and R. W. K. Honeycombe: Metall. Trans. A 10A (1979) 1049-1058.

7) Y. S. Shen, E. J. Zdanuk and R. H. Krock: Metall. Trans. 2(1971) 2839-2844.

8) V. A. Van Rooijen, E. W. Van Royen, J Vrijen and S. Radelaar: Acta Metall. 23(1975) 987-995.

9) S. W. Thomson and G. Krauss: Metall. Trans. 20A(1989) 22792288.

10) T. Nakahara, Y. Funakawa and T. Inazumi: Proc. of Thermomechanical Processing of Steels 1 (2000) 39-48.

11) M. Morita, N. Kurosawa, T. Kato, N. Aoyagi and T. Sakagami: CAMP-ISIJ 6 (1993) 1694.

12) K. Kunishige: Materia Japan 35(1996) 32-40.

13) Y. Funakawa, T. Shiozaki, K. Tomita, Y. Yamamoto and E. Maeda: ISIJ Int. 44(2004) 1945-1951.

14) F. G. Berry, A. T. Davenport and R. W. K. Honeycombe: Proc. of an International Symposium, Vol. 33, (IMM, 1968) pp. 288292.

15) S. Freeman: The Effect of Second Phase Particles on the Mechanical Properties of Steels, (ISI, London, 1971) pp. 152-156.

16) G. Spanos: Metall. Trans. A 23A (1992) 171-181.

17) Y. Funakawa and K. Seto: Tetsu-to-Hagané 93(2007) 49-56.

18) G. L. Dunlop and R. W. K. Honeycombe: Met. Sci. 8(1978) 367371.

19) T. Ariga, T-Yokota, K. Seto and C. Maeda: CAMP-ISIJ 20 (2007) 
1213.

20) M. Suwa, K. Sato, Y. Funakawa, T. Shinmiya and S. Mitao: CAMPISIJ 18 (2005) 1524.

21) S. Kobayashi, K. Kimura and K. Tsuzaki: Intermetallics $\mathbf{4 6}(2014)$ 80-84.

22) R. Lagneborg and S. Zajac: Metall. Mater. Trans. A 32A (2001) 39-50.

23) A. D. Batte and R. W. K. Honeycombe: J. ISI 211 (1973) 284289.

24) T. Sakuma and R. W. K. Honeycombe: Met. Sci. 18(1984) 449454.

25) C. Atkinson and P. Wilmott: Metall. Trans. A 22A (1991) 12191224

26) J. M. Gray and R. B. G. Yeo: Trans ASM 61(1968) 255-269.

27) F. B. Pickering and T. Gladman: ISI special report 81 (1963) $10-20$.

28) W. C. Leslie: Proc of The Strengthening of Carbon Steel by Small Addition of Columbium, (1963), pp. 333-346.

29) J. M. Gray, D. Webster and J. H. Woodhead: J. ISI 203(1963) $812-818$.

30) M. Tanino: J. Japan Inst. Met. Mater. 29(1965) 734-741.

31) F. B. Pickering and T. Gladman; Iron Steel Inst. special report 81 (1963) 10-20.

32 W. C. Leslie: Proc of N. P. L Symposium No. 15, The Relation Between the Structure and Mechanical Properties of Metals, (HMSO, London, 1963).

33) Y. Funakawa: Mater. Sci. Forum 706-709(2012) 2096-2100.

34) R. G. Baker and J. Nutting: J. Iron Steel Inst. 192(1959) 257268

35) R. A. Rick and P. R. Howell: Acta Metall. 31 (1983) 853-861.

36) T. Obara, G. J. Shiflet and H. I. Aaronson: Metall. Trans. A 14A (1983) 1159-1167.
37) V. D. Edmonds: J. ISI 210(1972) 363-365.

38) W. Roberts, A. Sandberg and T. Siwecki: Proc. of Vanitiec Seminar on Vanadium Steels, (1980) D1-D12.

39) M. Chen, M. Goune, M. Militzer, Y. Brechet and J. Yang: Metall. Trans. A 45A (2014) 5351-5361.

40) R. A. Rick and P. R. Howell: Met. Sci. 16(1982) 317-321.

41) R. Lagneborg and S. Zajac: Metall. Trans. A 32A (2001) 39-50.

42) R. Okamoto and J. Argren: Acta Mater. 58(2010) 4791-4803.

43) T. Murakami, H. Hatano, G. Miyamoto and T. Furuhara: ISIJ Int. 52(2012) 616-625

44) K. Kunishige, S. Sugisawa, K,. Kikuchi, Y. Toyota and Y. Masui: Sumitomo Metal Technical Reports 31(1979) 290-300.

45) M. Morita, T. Shimizu, O. Furukimi, N. Aoyagi and T. Kato: Materia Japan 37 (1998) 512-514.

46) T. Murakami, M. Kinefuchi, M. Nomura and Y. Mukai: J. Japan Inst. Met. Mater. 72(2008) 832-838.

47) K. Seto, Y. Funakawa and S. Kaneko: JFE Tech. Rep. 16(2007) $28-33$

48) Y. Funakawa, T. Fujita and K. Yamada: JFE Tech. Rep. 30(2012) $1-5$.

49) I. Nomura: Materia Japan 34(1995) 705-709.

50) T. Murakami, E. Kakiuchi, H. Hatano, T. Arikawa, H. Kakimoto and T. Choda: Kobe Steel Engineering Reports 61 (2011) 79-83.

51) M. Honda: The Special Steel 62 (2013) 99-11.

52) Y. Murase, N. Iwasa, Y. Takemoto and T. Senuma: Tetsu-toHagané 99(2013) 669-675.

53) Y. Ohmori: J. Japan Inst. Met. Mater. 15(1976) 93-100.

54) N. Kamikawa, G. Miyamoto, Y. Abe, Y. Funakawa and T. Furuhara: ISIJ Int. 54(2014) 212-221.

55) N. Kosaka and Y. Funakawa: ISIJ Int. 56(2016) 311-318.

56) N. Kamikawa, Y. Abe, G. Miyamoto, Y. Funakawa and T. Furuhara: ISIJ Int. 54 (2014) 212-221. 